\title{
A HISTOLOGICAL STUDY OF THE TESTES OF THE SOCKEYE SALMON (ONCORHYNCHUS NERKA) ${ }^{1}$
}

\author{
GEORGE F. WEISEL \\ University of Michigan, Ann Arbor, Michigan
}

THREE TEXT FIGURES AND TWO PLATES (TWELVE FIGURES)

\section{INTRODUCTION}

Most of the earlier investigations on the gonads of teleosts have been concerned with the lineage of germ-cells (Nussbaum, 1880; Eigenmann, 1891; Dodds, '10; Sink, '12; and Bachmann, '14). The structural development of the radialtype testis, as well as the history of the germ-cells in Cottus, was described by Hann ('27). Essenberg ('23) traced the development of the acinus-type testis in Xiphophorus. The structure of the mature testes has been described for Perca (Turner, '19), Gambusia (Geiser, '21), Gasterosteus (CraigBennett, '30), Fundulus (Matthews, '38), Phoxinus (Bullough, '39), and Galeichthys (Frederick, '41). These papers deal also with the reproductive cycle.

This study was undertaken to trace any correlations which might exist between the life history of the Pacific salmon, particularly of a certain landlocked type, and the histology of their testes. On reaching sexual maturity, the males of the Pacific salmon (the genus Oncorhynchus) exhibit an extreme development of the secondary sexual characters. A pronounced hump appears on their backs, their jaws become elongated and distorted, and the skin becomes thickened, so that the scales are deeply embedded. ${ }^{2}$ The males as well as the females die soon after their single spawning season.

${ }^{1}$ Accepted in partial fulfillment of the requirements for the degree of Master of Arts at Montana State University.

${ }^{2}$ This is the common appearance of the males. The sexually mature grilse does not develop these characteristics. Also, parrs of the king salmon which Rutter ('03) found to be precociously matured fail to develop secondary sex characters. 
As a basis for comparison, testes were obtained from rainbow trout in approximately the same stages of development as the salmon series. The rainbow (Salmo gairdnerii) does not develop secondary sex characters to so high a degree and can spawn more than once in its life span. Another point of difference is that the race of rainbow trout used in this investigation spawns in the spring whereas the type of salmon studied spawns in the late fall and early winter.

\section{MATERLALS AND METHODS}

The mature sockeye salmon (Oncorhynchus nerka) used for this study are the landlocked salmon found in Flathead Lake, Montana (fig. 5). On October 2nd, prior to the spawning period, adult salmon were caught by trolling. Those ready to spawn were obtained during the seining operations of the State Hatchery at Somers on November 15th. Salmon taken by means of a drag hook on January 4 th had obviously finished spawning; though still alive, all were in various stages of decay.

The rainbow trout and the immature sockeye salmon were procured from hatcheries on the Flathead drainage. Testes of the trout, to be compared with the testes of mature salmon, were from 3- and 4-year-old males taken from the stock pools on March 8th and April 13th. On May 16th trout which had been stripped a month previously were obtained. Immature 3-year-old salmon and 2-year-old trout were taken on December 3rd, January 4th, and March 8th.

The fishes were immediately weighed and measured in the fresh condition. The testes were weighed after fixation. The gonads and their ducts were removed in the field and placed in either Bouin's picro-formal, Zenker's fluid, or Mossman's mixture of alcohol-formalin-acetic acid. To insure fixation, the larger gonads were cut into small portions.

Tissues were embedded in paraffin and cut from $5 \mu$ to $8 \mu$ thick. Iron hematoxylin, destained with a saturated solution of picric acid, was used to stain most of the tissues. A counterstain of eosin was used on some slides. Sections stained in 
Ehrlich's acid hematoxylin counterstained with eosin, and also Mallory's triple stain proved valuable.

The small immature testes were cut either in cross or longitudinal section. The larger testes were cut as nearly as possible in the mid-region. Sections of the sperm duct, posterior to the testes, were taken half way between the testis and the urogenital sinus. Also longitudinal sections as well as sample cross sections, from various regions of the testes and ducts, were made.

\section{ACKNOWLEDGMENTS}

I am deeply grateful for the encouragement and guidance of Dr. Ludwig G. Browman under whose general direction this investigation was done. I am also indebted to Dr. Carl L. Hubbs of the University of Michigan for advice in revision of the manuscript. This study would not have been possible if it had not been for the fine cooperation of Dr. Gordon B. Castle and Dr. Philip L. Wright and for the material furnished by the federal Fish and Wildlife Service and the Montana Fish and Game Department.

\section{OBSERVATIONS}

\section{Immature testes}

The testes of the 3-year-old salmon (fig. 6) and the 2-yearold trout procured for this study are in approximately the same stage of development and are basically similar in their structural details. They are small paired elongated bodies, each suspended by a mesorchium from the ventral anterior portion of the air-bladder. A transparent membrane covers each testis. A thread-like sperm duct continues from their posterior end to the urogenital sinus.

The spermatic vein and artery are dorsally located, just ventral to the mesorchium. Numerous branches given off by these vessels traverse the strands of testicular stroma. Dorsal to the blood vessels there is a space of variable size which contains a light-staining liquid and an occasional lymphocyte. 
The space has no connection with the testicular canal and is interpreted as a space left by the incomplete fusion of the peritoneum when the gonad became suspended in the coelom.

The testicular portion of the sperm duct is a small cavity in the stroma near the mesorchium. It starts at about the anterior third of the organ as a slit-like lumen and becomes enlarged posteriorly. Short branches from the duct pass through the connective tissue of the testes to the more proximal nests of germ-cells.

The germ-cells of the immature testes are spermatognia. They are grouped in nests, which are surrounded by follicle cells. The nests are separated into lobules by fine partitions of connective tissue. In a cross section of a testis there are from one to twenty-five spermatogonia in a nest. As the cells increase in number, presumably by mitosis rather than by conversion from epithelial cells, the nests become larger and the germ-cells slightly smaller. The larger nests of germcells have a lumen in their center. Near the mesorchium the lumens of some of the nests of germ-cells become continuous with the secondary duets of the main sperm duct.

The spermatogonia are by far the largest cells in the immature testes. The diameters of 150 of these cells, selected at random from the testes of three different salmon, were $6.8 \mu$ to $12.4 \mu$ averaging $9.4 \mu$. For the same number of cells measured in the trout, the range was $5.8 \mu$ to $12.4 \mu$ and the average was $7.7 \mu$. The spermatogonia are spherical. They typically have one large spherical nucleolus, but there may be as many as three. In the clear nucleoplasm there is a system of delicate radiating fibrils which apparently have their origin in the nucleolus. The nuclear membrane is well defined, but the cell membrane is not. Counts of spermatogonia undergoing mitosis in the salmon testes were taken along linear distances from one side of the testis to the other by using a mechanical stage and a ruled ocular. There was an average of 6.4 cells per 1,000 in some active stage of mitosis (3,000 cells were counted in three different testes). There is no sign of degeneration among any of the germ-cells of the immature testes. 
In the immature salmon and trout studied there is no indication of the transformation of somatic epithelial cells into germ-cells. It is possible that such a transformation might take place in stages younger than those examined. The only germ-cells found in these fish are the spermatogonia. There is no indication that the salmon or the trout had reached sexual maturity in the parr period, as has been reported for some king salmon (Rutter, '03).

\section{Testes in maturation}

Testes in maturation were obtained on October 2, 1938 from two salmon whose secondary sexual characteristics were not yet fully developed. The length of the upper jaw averaged 1 $\mathrm{cm}$. less than the average for fifty completely matured salmon caught in the same year (table 1 ).

The salmon testes in maturation have a complex structure. The lobules are very intricate but run generally from the periphery toward a dorso-medial duct. The lobule septa are thin strands of connective tissue. The walls of the lobules are lined with large cysts of germ-cells. The testes, in consequence, appear to be made up of irregular chains of cysts. The cysts are in various stages of spermatogenesis. Each cyst is packed with cells which are in the same stage of maturation. There is no seriation of spermatogenesis from the cortex to the medulla of the testes. The cysts are enclosed in an extremely thin membrane of follicle cells which usually breaks in the spermatid stage. It is the breaking of the ripe cysts (to release their germ-cells) that forms and enlarges the Iumen of the lobules.

Along the walls of the lobules, and not infrequently embedded in the connective tissue, are occasional normal resting spermatogonia which have not formed the large cysts.

It is difficult to distinguish between the primary spermatocytes and the later generations of spermatogonia as they both have a nuclear diameter of about $6.8 \mu$. The material at hand shows no nucleoli in the primary spermatocytes. Most of the 
cysts contain primary spermatocytes undergoing a nuclear condensation into an apparent zygotene stage. Primary spermatocytes in other cysts have the greater portion of the chromatin material drawn to one pole so as to form a typical bouquet stage. No certain post-synaptic spiremes were observed. Later stages show no nuclear membrane, the small, mostly oval chromosomes lined up in the metaphase with definite spindle fibers formed, and the first maturation division completed.

The secondary spermatocytes have a nuclear diameter of $4.5 \mu$, two-thirds that of the primary spermatocytes. Since few resting secondary spermatocytes are present, the second maturation division probably takes place rapidly.

The spermatids have a nuclear diameter of $3.4 \mu$, one-half that of the primary spermatocytes. There is an obvious condensation of the spermatid nuclear material into a homogeneous dark-staining sphere.

The mature spermatozoön has an oval-shaped head, nar. rowest at its anterior end. The head stains an intense black in iron-hematoxylin preparations. The widest diameter of the head is approximately $1.1 \mu$ and the length of the tail piece three to four times as much. The sperm move to the center of the lobule's lumen where they become arranged so that their tails are to the center of the irregularly-shaped sperm masses. The sperm, unattached to any cells, remain free in the lumens of the lobules.

In the posterior third of the coelomic cavity, each testis is constricted into a duct which leads to the urogenital sinus. Sections show that the constricted portion contains testicular tissue for a variable distance posteriorly. The duct seldom becomes a simple tube, even when the testicular network is completely absent. The irregularly shaped walls of the duct send projections into the lumen, and there are often spermconducting tubules within the duct itself. The paired ducts do not fuse until they enter the urogenital sinus.

The extra-testicular portions of the genital duct in the October salmon contain no sperm, though there are sperm in 
the testicular portions. The epithelium is mostly tall columnar but may be cuboidal in the same section. Vacuoles $(2.3 \mu$ to $6.8 \mu$ in diameter) occur toward the apex of the epithelial cells. The vacuoles have no recognizable content and take no stain. The nuclei of the epithelial cells are mostly basal but may be apically or centrally located.

\section{Ripe testes}

The ripe testes studied were obtained at Flathead Lake from matured male sockeye salmon (fig. 5) which had developed secondary sexual characteristics similar to those of the ocean-running pink salmon (Oncorhynchus gorbuscha), as described by Davidson and Shostrom ('36). Table 1 shows the great increase in jaw length of the male as compared with the slight change in the female. The age of the anadromous

TABLE 1

Material studied.

\begin{tabular}{|c|c|c|c|c|c|}
\hline & $\begin{array}{l}\text { No. } \\
\text { OF } \\
\text { FISH }\end{array}$ & SEX & $\begin{array}{c}\text { AVGRAGE } \\
\text { LENGTH IN } \\
\text { CENTIMETERS }\end{array}$ & $\begin{array}{l}\text { AVERAGE } \\
\text { WEIGHT IN } \\
\text { GRAMS }\end{array}$ & $\begin{array}{c}\text { AVERAGE } \\
\text { LENGTH OF } \\
\text { JAW IN } \\
\text { CENTIMETERS }\end{array}$ \\
\hline Immature 3-year salmon: & 7 & male & 12.5 & 37.3 & 0.6 \\
\hline Dec., Jan., Mar. & 6 & female & 12.7 & 37.2 & 0.6 \\
\hline $\begin{array}{l}\text { Salmon in maturation } \\
\text { stages: Oct. }\end{array}$ & 2 & male & 31.1 & 737.1 & 2.7 \\
\hline Spawning salmon: & 50 & male & 27.0 & 510.3 & 3.4 \\
\hline Nov. & 8 & female & 27.9 & 440.5 & 1.7 \\
\hline Post-spawning salmon: & 8 & male & 26.5 & 435.5 & 3.4 \\
\hline Jan. & 1 & female & 27.3 & $\mathbf{3} 09.0$ & 1.5 \\
\hline $\begin{array}{l}\text { Immature 2-year trout: } \\
\text { Dec., Jan., Mar. }\end{array}$ & 4 & male & 12.9 & 49.4 & $\cdots$ \\
\hline $\begin{array}{l}\text { Spawning trout: } \\
\text { Mar., April }\end{array}$ & 8 & male & 21.8 & 274.5 & . \\
\hline $\begin{array}{l}\text { Post-spawning trout: } \\
\text { May }\end{array}$ & 6 & male & 19.7 & 167.3 & $\ldots$ \\
\hline
\end{tabular}

${ }^{1}$ Measurements of length were made from the posterior extremity of the pterotic bone to the end of the scales on the tail.

${ }^{2}$ Length of the upper jaw was measured, with dividers, from the middle of the external nares to the tip of the snout. 
sockeye, when sexually mature, varies from 3 to 8 years with the predominant age groups in the fourth and fifth year (Gilbert, '12; Gilbert and Rich, '27). Scales and otoliths were examined from salmon of both sexes taken in the spawning run of November, 1941, at Somers. The scales which were extracted just behind the operculum had the least resorbtion and could be easily read. All of these fish were found to possess three annuli on their scales and otoliths, which would indicate that they were 4 years of age.

The relationship of the mesorchium has changed in the mature testes as compared with the immature testes. In the immature testes the mesorchium suspends the testis from the dorsal end, the testicular duct and blood vessels also being dorsally located. The ripe testis has the mesorchium attached to its medial surface, and the testicular duct and blood vessels are located on the dorso-medial side of the testis. From its principal point of attachment, the mesorchium is incompletely fused along the dorso-medial surface of the testis. The change in position of the mesorchium is probably brought about by the growth of the testes, which crowd against the stomach and liver, located ventral and medial to them. This crowding results in a rotation of the testes away from these organs, carrying the once dorsally located hilus to a dorso-medial position. No similar rotation is seen in the duct continuing posteriorly from each testis.

The paired ripe testes of the salmon and trout are distended with a liquid mass of milt. They are finger-like organs, with their rounded anterior ends against the anterior wall of the coelom.

The lobules in the ripe testes are of various sizes and shapes and have no regular structure. Generally they run in a ventral to dorsal direction to empty into the sperm duct. The lobules may branch as many as ten to twenty times. Most of the branches end blindly before reaching the testis wall. The serial reconstruction of a portion of a testis (figs. 7 to 15) shows the complexity of the arrangement of the lobules. The walls of the lobules are narrow partitions of connective tissue 
with the dorso-medial hilus haxing the central portion of connective tissue, though even here the stromal tissue consists only of narrow strands. The lumens of the lobules are filled with sperm.

The cysts of germ-cells undergoing maturation have disappeared in the ripe testes, but irregularly placed along the lobule walls or embedded in the stroma are occasional resting spermatogonia (fig. 1). In the salmon they are present singly or in groups of from two to ten, surrounded by follicle cells.

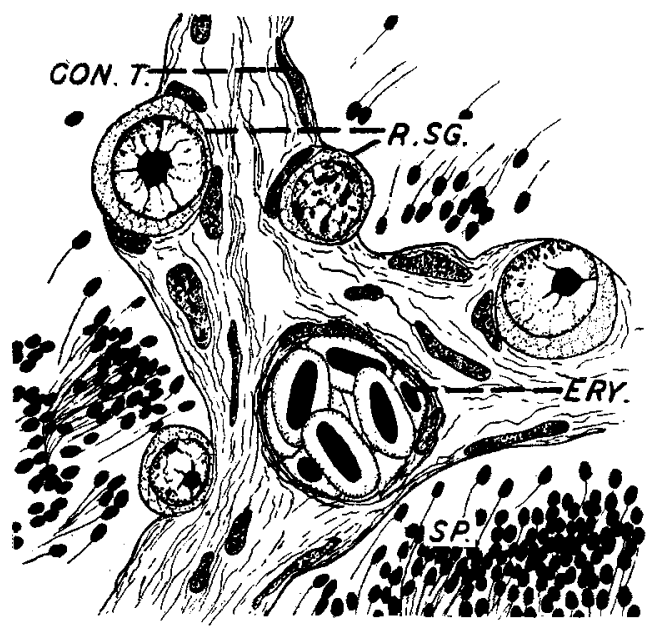

Fig. 1 Drawing of a section of testis from a spawning salmon to illustrate resting germ-cells before degeneration. Other portions of the same testis show degeneration (fig. 2). Abbreviations: con.t., connective tissue nucleus; ery., erythrocytes; r. sg., resting spermatogonia; sp., spermatozoa. $\times 1500$.

The numbers of these cells vary considerably in individual trout. In some, the resting spermatogonia literally line the lobule walls, whereas, in others, as in the salmon, they appear only at irregular intervals.

A majority of the spermatogonia in the salmon have developed clear vacuoles (fig. 2). In some of the salmon testes this vacuolization is so frequent that it is difficult to find unaffected resting spermatogonia. Vacuoles also appear in follicle cells and epithelium of the lobules but not in the connective tissue. 
Spermatogonia which are vacuolated lose their typical circular outline, and the nucleus assumes a sickle-form as though forced into that shape by pressure of the vacuole. In some extremely modified cells the vacuoles have broken into the lumens. The nuclei of vacuolated spermatogonia lose their nucleoli and the chromatin becomes granular, taking a darker stain than the unaffected spermatogonia. The cytoplasm of

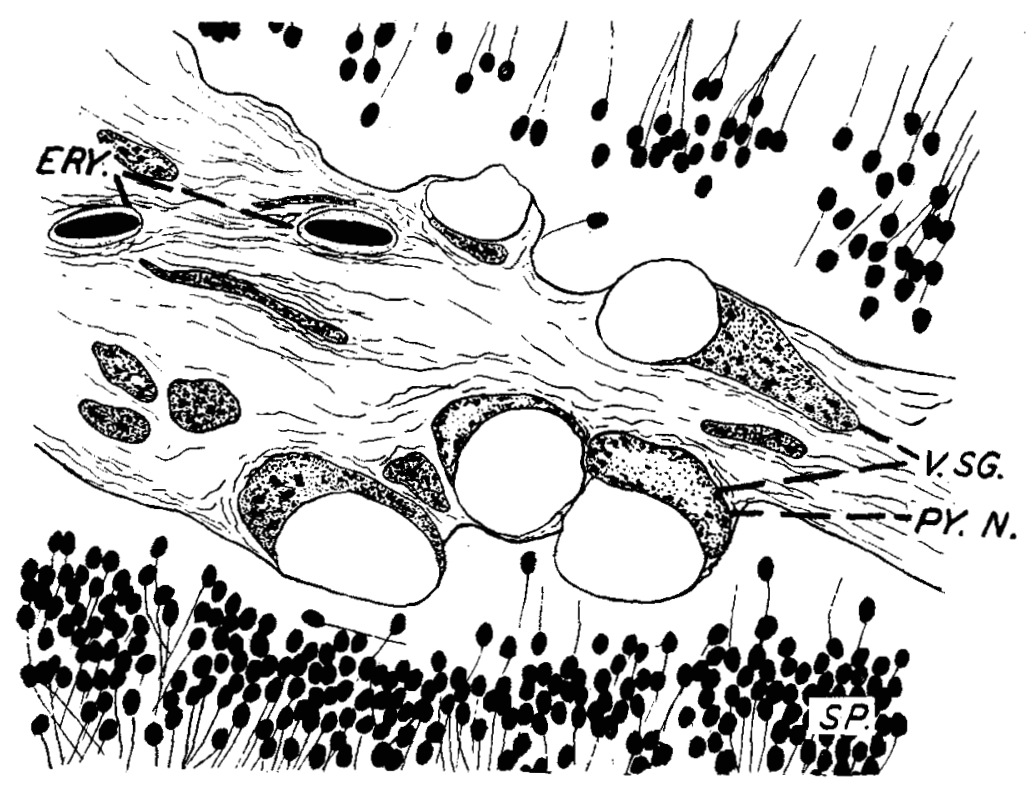

Fig. 2 Drawing of a section of the same testis showing a region of epithelial degeneration in spawning salmon. Abbreviations: ery., erythrocytes; py.n., pyenotic nucleus; sp., spermatozoa; v. sg., vacuolated spermatogonia. $\times 1500$.

the vacuolated cells takes a basic stain. In the cells of the trout testes there is complete absence of any sign of vacuolization or degeneration.

The epithelial cells of the sperm duct in the salmon (but not those of the urogenital sinus) are also vacuolated and the nuclei show the early developments of pycnosis. A series of measurements of these cells in the extra-testicular portion of the sperm duct were made for comparing the different stages 
in the salmon and trout (table 2). The cells of the duct epithelium of the November salmon are cuboidal and show a marked decrease in height as compared to the October salmon. The vacuoles have increased in number and in size. Their location is either apical or lateral to the nucleus. The vacuoles in the October salmon might be explained, on their appearance, as associated with secretion. In the November fish

TABLE 2

Vacuolization and cell heights in the epithelium of the extra-testicular portion of the sperm duct. ${ }^{4}$

\begin{tabular}{|c|c|c|c|c|c|}
\hline & & $\begin{array}{l}\text { AVERAGE NO. } \\
\text { OF VAOUOLES TO } \\
\text { EVERY } 100 \\
\text { NUCLEI }\end{array}$ & $\begin{array}{l}\text { AVERAGE } \\
\text { VACUOLE } \\
\text { DIAMETER }{ }^{2}\end{array}$ & $\begin{array}{l}\text { AVERAGE } \\
\text { EPITHELIAT } \\
\text { HEIGHT }^{3}\end{array}$ & $\begin{array}{l}\text { APPROXIMATE } \\
\text { DIAMETER OF } \\
\text { DUCT LUMEN }{ }^{4}\end{array}$ \\
\hline \multirow{3}{*}{$\begin{array}{l}\text { October salmon in } \\
\text { maturation }\end{array}$} & (1) & 54 & $4.0 \mu$ & $28.4 \mu$ & $1.0 \mathrm{~mm}$ \\
\hline & (2) & 34 & $3.5 \mu$ & $30.2 \mu$ & $0.8 \mathrm{~mm}$. \\
\hline & av. & 44 & $3.8 \mu$ & $29.3 \mu$ & $0.9 \mathrm{~mm}$ \\
\hline \multirow{3}{*}{$\begin{array}{l}\text { November } \\
\text { spawning salmon }\end{array}$} & (1) & 86 & $5.6 \mu$ & $14.5 \mu$ & $1.7 \mathrm{~mm}$ \\
\hline & (2) & 98 & $5.7 \mu$ & $13.9, \mu$ & $1.7 \mathrm{~mm}$ \\
\hline & av. & 92 & $5.7 \mu$ & $14.2 \mu$ & $1.7 \mathrm{~mm}$ \\
\hline \multirow{3}{*}{$\begin{array}{l}\text { January post- } \\
\text { spawning salmon }\end{array}$} & (1) & 63 & $6.8 \mu$ & $13.8 \mu$ & $1.2 \mathrm{~mm}$ \\
\hline & (2) & 85 & $7.1 \not \mu$ & $11.9 \mu$ & $1.5 \mathrm{~mm}$ \\
\hline & av. & 74 & $7.0 \mu$ & $12.9 \mu$ & $1.4 \mathrm{~mm}$ \\
\hline \multirow[t]{2}{*}{$\begin{array}{l}\text { March spawning } \\
\text { trout }\end{array}$} & $\begin{array}{l}(1) \\
(2)\end{array}$ & none & none & $\begin{array}{r}11.8 \mu \\
8.2 \mu\end{array}$ & $\begin{array}{l}0.9 \mathrm{mmm} . \\
1.3 \mathrm{~mm} .\end{array}$ \\
\hline & av. & & & $10.0 \mu$ & $1.1 \mathrm{~mm}$. \\
\hline \multirow[t]{2}{*}{$\begin{array}{l}\text { April spawning } \\
\text { trout }\end{array}$} & $\begin{array}{l}(1) \\
(2)\end{array}$ & none & none & $\begin{array}{r}10.3 \mu \\
9.2 \mu\end{array}$ & $\begin{array}{l}1.2 \mathrm{~mm} \text {. } \\
1.3 \mathrm{~mm} \text {. }\end{array}$ \\
\hline & av. & & & $9.8 \mu$ & $1.3 \mathrm{~mm}$. \\
\hline \multirow{2}{*}{$\begin{array}{l}\text { May post- } \\
\text { spawning trout }\end{array}$} & (1) & & גרוח & $9.7 \mu$ & $1.4 \mathrm{~mm}$. \\
\hline & av. & IIIIIE & 11010 & $9.4 \mu$ & $1.3 \mathrm{~mm}$. \\
\hline
\end{tabular}

${ }^{1}$ One-hundred fields $45.4 \mu$ in length were measured in two fish from each stage.

2 The diameter of the first vacuole on the right side of each field was measured.

${ }^{3}$ For the salmon, the height of the epithelial cells was taken in the center of each field where vacuole and nuclear counts were made. For each trout, fifty epithelial cells were chosen at random.

- Comparative diameters of the duct lumens made by taking the average of the widest horizontal and vertical diameters. 
the vacuoles are clearly products associated with the degeneration of the cells. The lumens of the sperm duct in the November salmon are distended with milt so as to increase the average diameter to about twice that of the lumens in the October salmon. This distension may in part account for the reduction of the heights of the epithelial cells.

The sperm ducts of the matured March and April trout are also distended with milt. The epithelium varies from columnar to cuboidal in a single section. There is no significant difference between the epithelial cell heights measured from trout taken in March and trout taken in April. The nuclei of the epithelial cells are nearly all centrally located. There is no sign of vacuolization nor of secretion in the epithelium.

\section{Post-spawning testes ${ }^{3}$}

The material for the study of the testes after spawning was removed from salmon which were caught in January. These fish, though living, were all in various stages of decay. In the most extreme specimens the caudal and dorsal fins were rotted off to the base of the fin rays, and the flesh along the dorsal ridge of the hump had turned yellow. In less extreme cases only the dorsal and caudal fins showed signs of rot. Many of the dead fish found washed up on the beach showed no more advanced stages of rot than actively swimming fish which were collected. This decay was not the result of migratory injuries as the salmon reached the spawning grounds in apparently good condition. Their migration is only from the deeper portions of the lake to the shore-line.

The testes examined for the post-spawning trout were taken on May 16th, from fish which had been stripped of their milt 3 weeks previously. These trout appeared to be normal in all respects.

The weight of the testes from ten salmon which had finished spawning averaged $0.4 \%$ of total body weight as compared to $0.8 \%$ average for testes from ten fish taken during

${ }^{3}$ Rutter ('03) estimates 2 weeks for the length of life of the king salmon after reaching the spawning grounds. 
the spawning run in November. The average weight of the testes from six post-spawning trout was $0.9 \%$ of the total body weight compared to $1.2 \%$ for six trout taken in March and April.

Because of contraction of the testes after the expulsion of the greater mass of the sperm, the septa of the lobules in both

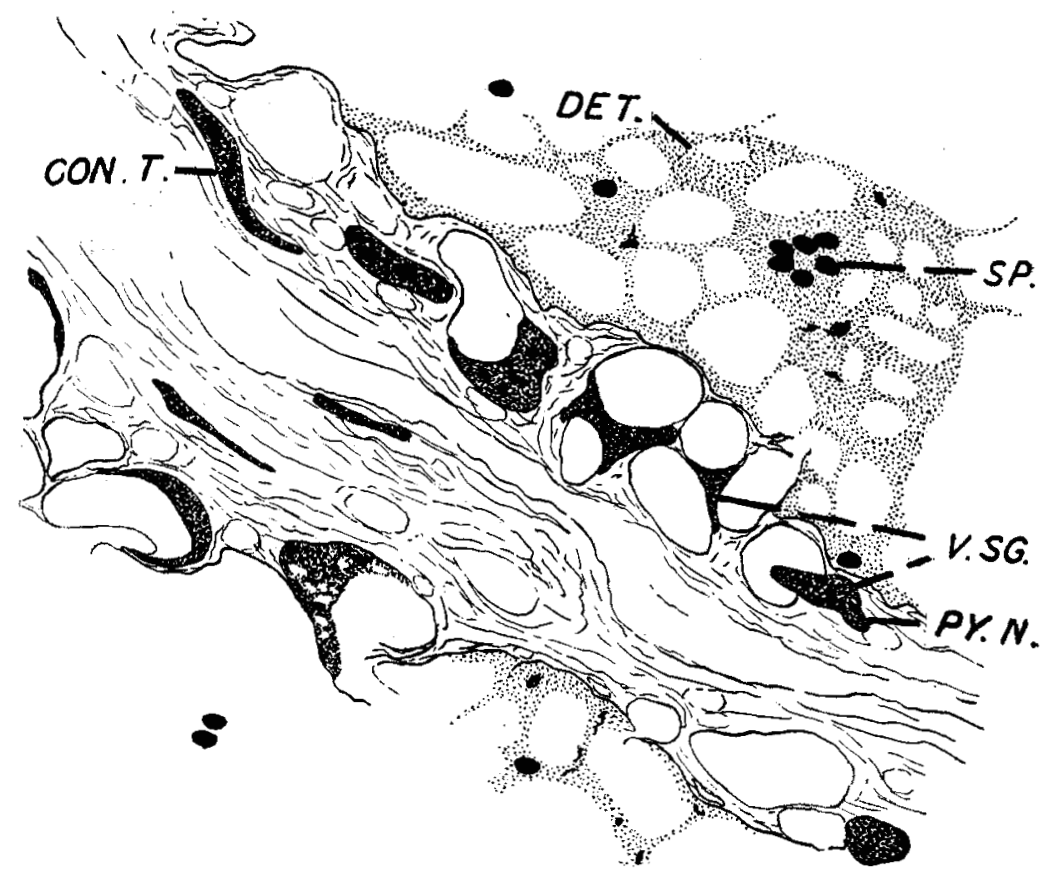

Fig. 3 Drawing of a section of testis from a post-spawning salmon to illustrate more extreme degeneration of testicular tissues. Abbreviations: con.t., connective tissue nucleus; det., detritus; py. n., pyenotie nueleus; sp., spermatozoa; v. sg., vacuolated spermatogonia. $\times 1500$.

salmon and trout appear like a complicated maze. A few sperm remain in the lobules and ducts. An examination of dead salmon also shows the presence of a few sperm in the testes.

Cells lining the lobule walls of the salmon testes are much more vacuolated than those in the ripe testes and exhibit unmistakable signs of necrosis (fig. 3). In sections under low 
objective, the lobule septa look not unlike adipose tissue from which the fat had been dissolved. The cells of the stroma, as well as the spermatogonia and epithelial cells, are vacuolated. The spermatogonia, epithelial cells and follicle cells are the first affected with vacuolization as there is no evidence of vacuolization among stroma cells in the ripe testes. It is impossible to stain the testicular tissue of these post-spawning salmon and get good differentiation. Vacuoles occur in nearly all the cells lining the lobule walls and are extensive throughout the stroma. Many of the vacuoles along the lobule walls have broken. The nuclei are markedly pycnotic, having different degrees of staining capacity depending on the amount of pycnosis which they have undergone. The most shrunken cells take the deepest staining due to more condensed cytoplasmic and nuclear material. Karyorhexis is not evident. There is a liquefaction of many of the cells, so that some of the lumens contain a granular liquid with scattered nuclei and no distinguishable cell walls. The peritoneal cells of the membrane covering the testes and the cells of the mesorchium show only slight signs of necrosis. The epithelial cells of the testicular portion of the sperm duct are pycnotic, and the lumen of the duct contains a liquid with fragments of cells sloughed off from the epithelium. The blood vessels and capillaries are full of erythrocytes, but these cells too are necrotic and in some cases have undergone liquefaction.

The picture of degeneration is duplicated in the extratesticular portion of the ducts of the post-spawning salmon. The average epithelial height is approximately the same as in the spawning fish, but the size of the vacuoles averages $1.3 \mu$ larger in diameter than in the spawning salmon (table 2). The vacuoles are fewer than in the spawning salmon, but a number of the vacuoles seem to have fused and many of them have broken. In places along the duct wall the epithelial cells have undergone cytolysis so that the vacuoles are obliterated. Most of the epithelial nuclei are shrunken in various stages of pycnosis. The cytoplasm takes a basic stain. The con- 
nective tissue of the duct of the salmon with the more rotted fins and hump also shows signs of necrosis.

The post-spawning testes of the trout are similar to testes from spawning trout, excepting that the volume of sperm present is greatly reduced. They certainly show no signs of vacuolization nor of necrosis in any of the testicular cells. An occasional spermatogonium can be found undergoing division, presumably in preparation for the next spawning season. The spermatogonia are surrounded by smaller, irregularly shaped follicle cells which will form the fine membrane that encloses the large cysts of germ-cells in maturation. The epithelium of the sperm duct has a normal appearance and approximately the same average cell height as in the spawning fish.

\section{DISCUSSION}

The structure of immature salmon and trout testes indicates that these organs pass through a development similar to that of Cottus bairdii, as described by Hann ('27). A radial type of structure is evident. The blood vessels and the main testicular duct are situated in a dorsal hilus as in Cottus, and, from the testicular duct, secondary ducts branch off through the stroma cells. A few of the secondary ducts reach nests of germ-cells to incorporate them in a system of tubules.

Testes in maturation stages indicate that the secondary testicular ducts of the immature testes have become continuous with the lumens of the germ-cell nests, so that the germcells come to line the walls of the lobules. The lobules are comparable to lobate tubules, connected directly or indirectly with the main sperm duct. Each primary spermatogonium lining the lobule walls undergoes successive division to form eysts of germ-cells enclosed in a delicate membrane of follicle cells. A few spermatogonia, however, remain in a resting condition and do not form large cysts. Maturation stages are completed in the cysts but the membrane breaks in the spermatid or spermatozoön stage, freeing the germ-cells. The spermatozoa are not retained in spermatozeugmata as in the poeciliids (Henn, '16). 
In the lobule structure the matured salmon and trout testes are essentially similar to the testes of the perch, as described by Turner ('19), except that the salmon and trout lobules branch many more times. Although the dorso-medial hilus of the salmon and trout testes contains the central portion of connective tissue, there is no concentration of connective tissue which might be homologized to a connective-tissue core such as is found in the perch ('Turner, '19) or in Lebistes (Dildine, '36). The small amount of interstitial tissue present in the salmon and trout testes is confined to the narrow septa of the lobules. The stains employed yielded no indications that any of these interstitial cells have a secretory function.

The sources of the seasonal supply of germ-cells in the rainbow trout is undoubtedly similar to the source described for Cottus (Hann, '27), Fundulus (Matthews, '38), and Phoxinus (Bullough, '39). Resting germ-cells remain along the sides of the lobules. At the end of each breeding season, these germ-cells divide to form eysts filling the lobules. In the salmon the spermatogonia become vacuolated during the spawning period and then undergo pycnosis. In the author's opinion the degeneration of these cells is one of the senile changes which precedes the salmon's death (but is not necessarily a factor causing death). If such degeneration did not occur, the spermatogonia, remaining along the lobule walls, could fill the lobules with cysts of germ-cells by successive division.

There is no indication that the spermatogonia present had migrated from a cord of germ-cells outside the testes to their position along the lobule walls, as Turner ('19) suggested for the perch, nor is there any reason to believe that they are formed from peritoneal cells.

Vacuolization is first observed in the epithelial cells of the extra-testicular portion of the spem duct taken from salmon with testes in maturation. At this stage the vacuoles appear as though they might be associated with secretion. In testes from spawning salmon the vacuoles become definitely a part of the degeneration of the cells. As the cells become vacuo- 
lated, they show a loss of staining properties and cellular shape. In the spawning salmon this condition occurs not only in the epithelial cells of the sperm duct but also in the spermatogonia and follicle cells. The testes in post-spawning salmon have the nuclei of the degenerating cells markedly pycnotic and cytolysis obliterates many of the cells.

Testes and sperm ducts procured from trout during the spawning season and 3 weeks after they had been stripped show no signs of disintegration in any of their cells. The trout testes and the salmon material were treated for histological study in a manner as similar as possible.

In the vacuolization of the testicular tissues the mature Pacific salmon correspond in many ways with hybrid sunfishes. The epithelial cells of the centrarchid hybrids were found by Hubbs and Hubbs ('33) to show various stages of disintegration. It was thought that this degeneration of the testes was one reason for the observed infertility of the hybrids. In the salmon, which display similar pycnotic nuclei and protoplasmic vacuoles, the sperm is viable. Spermatogenesis seems to progress normally except for the resting spermatogonia which undergo necrosis after the mature sex products are formed.

Pycnotic and vacuolated cells were found by Matthews ('38) in the medulla of Fundulus testes. The cells that undergo this degeneration are the only cells in the testes which, in his opinion, might be called interstitial cells, but he could find no evidence of their being secretory. The degeneration of the "interstitial cells" in Fundulus takes place after the sperm are shed which, in the sex cycle, is only a little later than the time when the degenerative stages appear in the salmon testes. However, this necrotic condition as found in Fundulus appears to be confined to certain cells in the testicular medulla, and therefore to have no direct relation with the germ-cells.

Soon before death after spawning terminates the life cycle of the male and female Pecific salmon there are exhibited degrees of external decay in certain body regions. This decay is not, as some have thought, the results of an arduous spawning 
migration, for the race investigated has no extensive run and arrives on the spawning grounds in sound condition. The necrotic state found in the salmon testes is another of the signs of the approaching death of the animal.

Inanition may be one explanation for the early appearance of degeneration among the spermatogonia in the otherwise apparently normal salmon at the time it is ready to spawn. The Pacific salmon practically cease to feed during the spawning run. They rely on stored fats for maintenance and development of sexual products (Green, '09; Davidson and Shostrom, '36). Rats fed a standard casein diet maintained their growth and health but underwent degeneration of the testes (Mason, '26). Several hundred salamanders (Plethodon) when starved showed a degeneration of primary spermatocytes and an inhibition of further formation of spermatocytes (Burger, '37).

\section{SUMMARY}

1. To trace correlations which might exist between the peculiar life history of the Pacific salmon, which always die after the first spawning, and the histology of their testes, these organs were procured from sockeye salmon in different stages of development and compared with testes from rainbow trout in approximately the same stages.

2. Testes of immature salmon and trout are similar. They have a radial type of structure in which secondary ducts branch from a main dorsal testicular duct, and the lumens of the secondary ducts connect with lumens formed in the nests of germ-cells. The germ-cells are thus incorporated into a complex system of tubules.

3. The adult salmon and trout have the same basic structure. Their testes are divided by connective-tissue partitions into complicated lobules (modified tubules) which empty into a main dorso-medial testicular duct.

4. During maturation the lobules of the salmon testes are packed with cysts of germ-cells in various stages of spermatogenesis. The cysts break in the spermatid or spermatozoan 
stage so as to give the lobules a patent lumen containing a loose mass of germ-cells. Vacuoles occur in many of the epithelial cells of the extra-testicular sperm duct in the salmon at this stage.

5. In the spawning season the salmon testes exhibit vacuolization and pyenosis in the epithelial cells lining the ducts, in the spermatogonia, and in the follicle cells. This condition is completely absent in trout testes.

6. After the spawning season in the salmon the epithelial cells of the testicular ducts, the spermatogonia, and follicle cells are definitely pycnotic. Vacuoles increase in size as compared to those in spawning salmon. Neither pycnosis nor vacuolization occurs in cells of the post-spawning trout testes and genital ducts. The vacuolization in the cells of the salmon testes is part of a necrotic condition. The necrotic changes are a sign of the approaching death of the organism.

7. Quiescent spermatogonia, but no spermatocytes or spermatids, are present in the spawning and post-spawning salmon and trout. Enough spermatogonia remain after the spawning period to replenish the testes with sperm for successive spawning seasons, but in the Pacific salmon the quiescent spermatogonia commence to degenerate during the single spawning season.

\section{IITERATLRF CITED}

BachmanN, F. M. 1914 The migration of the germ-cells in Ameiurus nebulosus. Biol. Bull., vol, 26, pp. 351-366.

Bulfough, W. S. 1939 A study of the reproductive eycle of the minnow (Phoxinus laevis) in relation to the environment. Proc. Zool. Soc. London, vol. 109, pp. 79-102.

BURGER, J. W. 1937 The relation of germ-cell degeneration to modifications of the testicular structure of plethodontid salamanders. J. Morph., vol. 60 , pp. $459-487$.

CRAig-Bennets, A. 1930 The reproductive cycle of the three-spined stickleback. Royal Soc. London, Phil. Trans., B. 219, pp. 197-279.

Davidson, F. A., AND O. E. Shostrom 1936 Physical and ehemical changes in the pink salmon during the spawning migration. U. S. Bur. of Fish,, Investigational Report no. 33, vol. 2, pp. 1-37.

Dildine, G. C. 1936 Studies in teleostean reproduction. 1. Embryonic hermaphroditism in Lebistes reticulatus. J. Morph., vol. 60, pp. 261-277. 
Dopds, G. S. 1910 Segregation of the germ-cells of the teleost, Lophius. J. Morph., vol. 21, pp. 563-595.

ErgenmanN, C. H. 1891 On the precocious segregation of the sex-cells in Cymatogaster aggregatus. J. Morph., vol. 5, pp. 481-493.

Essmanbra, J. M. 1923 Sex-differentiation in the viviparous teleost Xiphophorus helleri. Biol. Bull., vol. 45, pp. 46-96.

Frederick, J. N. 1941 Seasonal histological changes in the testes of the seacat, Galeichthys felis. Anat. Rec., vol. 81, pp. 27.

Geiser, S. W. 1921 Seasonal changes in the testes of Gambusia affinis, the top minnow. 19th Annual Meeting Am. Soc. Zool., pp. 32-33.

Gilbert, C. H. 1912 Age at maturity of the Pacific coast salmon of the genus Oncorhynchus. Bull U. S. Bur. of Fish., vol. 32, pp. 1-22.

GILBERT, C. H., AND W. H. RICH 1927 Investigations concerning the red-salmon runs to Karluk River, Alaska. Bull. U. S. Bur. of Fish., vol. 43, part 2, pp. 1-69.

Greene, C. W. 1909 The migration of salmon in the Columbia River. Bull. U. S. Burr. of Fish., vol. 29, pp. 129-148.

HANN, H. W. 1927 The history of the germ-cells of Cottus bairdii. J. Morph., vol. 43 , pp. 427-497.

HenN, A. W. 1916 On various South American poeciliid fishes. Ann. Carn. Mus., vol. 10, pp. 93-142.

HuBBs, C. L., AND L. C. HurBs 1933 The inereased growth, predominant maleness, and apparent infertility of hybrid sunfishes. Pap. Mich. Acad. Sci., Arts and Letters, vol. 17, pp. 613-641.

Mason, K. E. 1926 Testieular degeneration in albino rats fed a purified food ration. J. Exp. Zool., vol. 45, pp. 159-230.

MATthews, S. A. 1938 The seasonal cyele in the gonads of Fundulus. Biol. Bull., vol. 75, pp. 66-74.

Nussbaum, M. 1880 Zur Differenzierung des Geschlechts im Tierreich. Arch. Mikr. Anat., Bd. 18, S. 1-121.

RUTTER, C. 1903 Natural history of the quinnat salmon. Extract from U. S. Fish. Comm. Bull. for 1902, pp. 65-141.

Sink, E. W. 1912 The origin of the germ celis in the toadfish (Opsanus tau). 14th Rept. Mich. Acad. Sci., pp. 212-216.

Turner, C. L. 1919 The seasonal cycle in the spermary of the perch. J. Morph., vol. 32 , pp. 681-711.

\section{PI ATE 1}

\section{EXPLANATION OF FIGURES}

4 Tmmature hatchery-raised male sockeye salmon. Three years of age. Length, $12 \mathrm{~cm}$.

5 Mature male sockeye salmon at time of spawning. Four years of age. Length, $28 \mathrm{~cm}$.

6 Cross section of an immature salmon testis. $\times 85$. a. bl., air-bladder; bl. v., blood vessel; c., capillary; int.m. s., intermesorehial space; n. g., nests of germcells; sec.t. d., secondary testicular duct; t. d., testicular duct. 

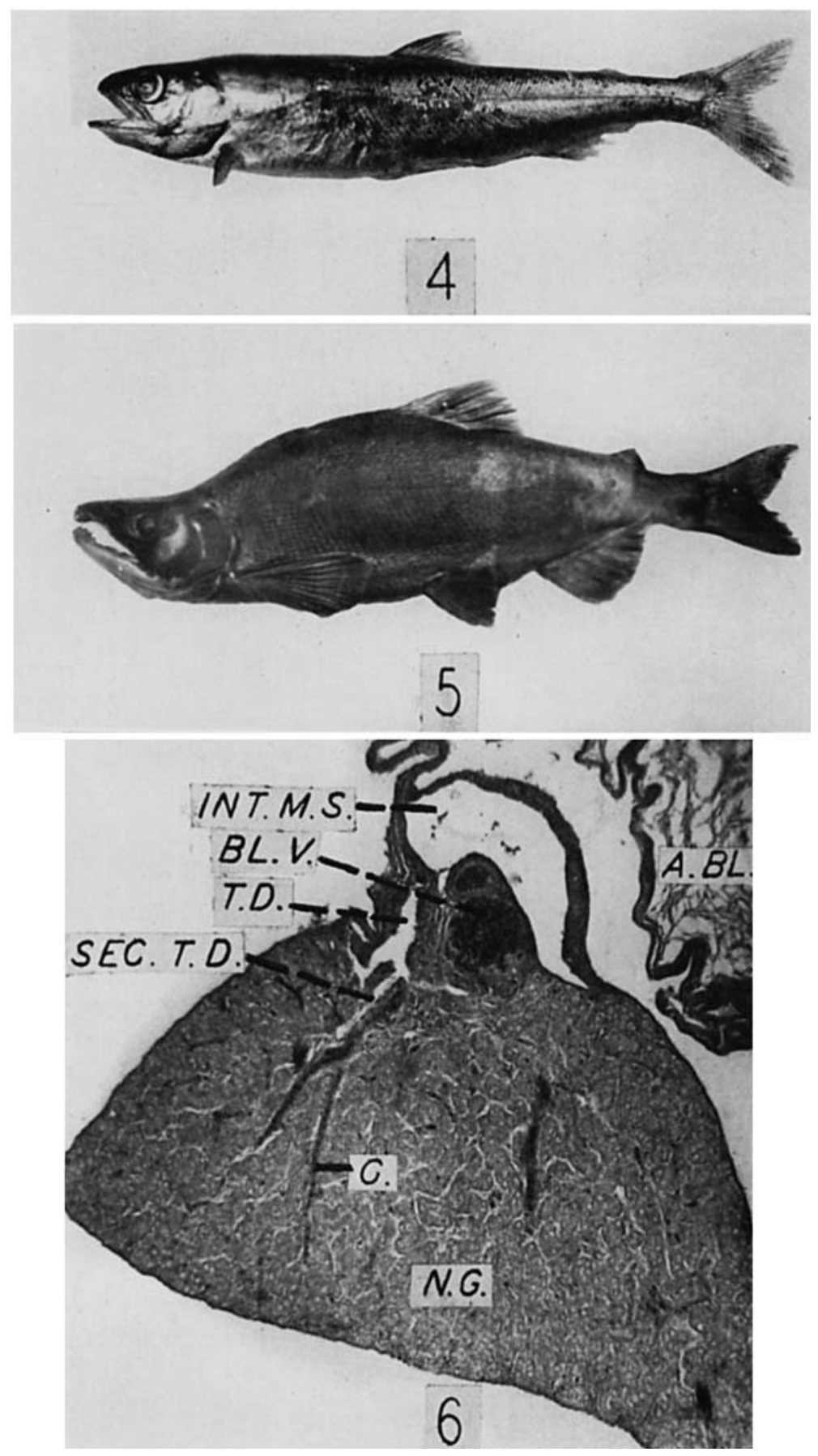
PLATE: ㄴ

EXPLANATION OF FIGTRES

Figures 7 to 15 are a scrial reconstruction of at portion of a fully matured salmon testis. Figures drawn ly means of a camerat lucida from sections $8 \mu$ thick. Mag. nification $\times 12$. The lobules showing comnection with the main sperms dnet are filled in solidly. b. .., blood ressel; l. l., lumen of lolule; l. s., lobule spetum; t. d., testicular duet. 

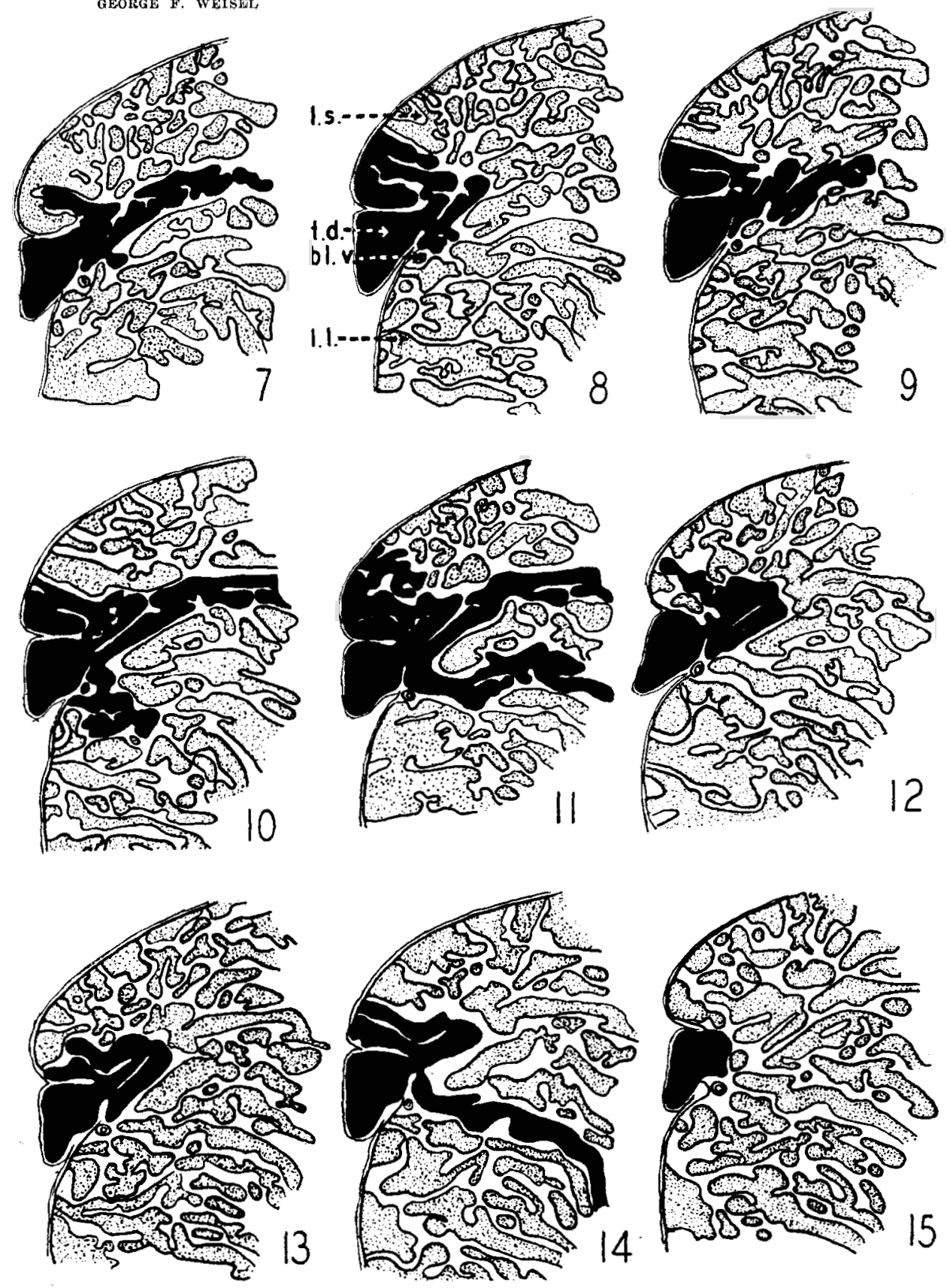